\title{
Assessing the impact of land use on triggering Landslides: A case of Sabaragamuwa Province, Sri Lanka
}

\author{
B.W.G.I.D.Gunarathna*, A.B.Jayasinghe, C.C.Abenayake, P.K.S. Mahanama \\ Department of Town \& Country Planning, University of Moratuwa 10400, Sri Lanka
}

\begin{abstract}
Landslide is a result of a complex spatial-temporal interaction of geological, geomorphological, climate and land use factors. Dynamics of geological, geomorphological and climate factors expands over relatively longer periods whilst land use change in short run. Hence, land use has a significant influence on landslide frequency and distribution, even in a short time span. However, limited studies have been carried out to investigate the relative contributions of the changes of different land use types in triggering landslides. This study has analyzed land use changes occurred in Sabaragamuwa Province, Sri Lanka over a period of ten years and assessed the effect of specific land use changes on landslides. The study is executed in four phases. Firstly, study mapped locations of landslides in QGIS environment. For this purpose, the study used secondary data which has been obtained from National Building Research Organization, Sri Lanka. Then the study analyzed the land use changes at landslide occurrence locations including a range of spatial buffer zone areas. MOLUSCE (Modules for Land Use Change Evaluation) plugin in QGIS was utilized to identify the land use changes in each spatial buffer zone area. Thirdly, the study computed the magnitude of landslide damage of each location based on five criteria as number of deaths, number of injured people, number of partial damaged houses, number of fully damaged houses and number of affected people. Then, the study analyzed the relationship between the magnitude of a landslide damage and land use changes. For this purpose, the study utilized spatial analysis tools in QGIS environment. The results revealed that land use changes such as forest to rubber, rubber-to-garden, rubber-to-any, teato-rubber, tea-to-any, forest-to-any have reported a greater influence on frequency of occurrence and the magnitude of landslide damage. These findings provide useful inputs to minimize landslides in the fields of land use planning and disaster management.
\end{abstract}

Keywords: MOLUSCE, QGIS, Land use changes, Landslide, Planning and disaster management

\section{Introduction}

Natural disasters have become a global development challenge that cause major damages to lives, properties and livelihoods (Ranjan \& Abenayake, 2014). Hence, human settlements are in an urgent need for disaster risk reduction initiatives to minimize the adverse impacts.

Landslide is the most frequent type of natural disasters reported in mountainous regions. Occurrence and frequency of landslide are caused by natural factors such as soil cover, slope stability, hydrology, drainage, precipitation and land form (Cruickshanka, 1995) as well as anthropogenically- induced factors such as land use and

\footnotetext{
* Corresponding Author:

Email address: darsinoka@gmail.com

DOI: http://doi.org/10.4038/bhumi.v6i2.42
}

management. "Different land use types may control the stability of slopes, and in particular, slope stability is improved by vegetation ... and hydrological features" (Greenway, 1987). Works of Beek, et al., have applied "a physical model to a $1.5 \mathrm{~km}^{2}$ catchment in the Alcoy region ... to assess the key effects of land use change on the spatial and sequential activity of slope variability. They have observed that the abandonment of cultivated grounds encourages an important reduction in land sliding incidence, and in deposit distribution" (Beek \& Asch, 2004). Similarly, a research conducted in Taihe area in Taiwan has reaveled a relationship between changes in vegetation cover over the landslide frequency - area distribution. Recent works focused on the effects of 
human-induced land use variations on slope stability have revealed that in populated regions, the impact of human activities significantly increases the initiation and reactivation of landslides (Bakker, et al., 2005); (Alewell $\&$ Meusburger, 2008); (Eeckhaut, 2009).

Rossi et.al. have worked in Messina, Italy "to understand the effect of land use change on the vulnerability zonation using different land use scenarios" (Rossi, Mondini, Busca, \& Reichenbach, 2014). Further, that study has evaluated and quantified the effect of land use change over a period of 60 years by the land susceptibility zonation. The study has developed a method to evaluate the consequences of land use change on landslide vulnerability and risk.

Recent works of Giuseppina et.al in Italy; Rio Frate, Versa and Alta Val Tidone area have examined the land use changes, "specifically by studying the time based changing aspects of land use differences, specifically in abandoned agricultural lands". The results revealed the abandoned cultivated lands, which were regularly recovered through the natural grasses, shrubs, as the land use change class as the most prone areas to shallow landslides (Giuseppina, Bordoni, \& Meisina, 2017).

Acknowledging the fact that landslide is a natural hazard, management of land use provides an effective solution to control the probability of landslide incidences. Scientifically validated research on the magnitude of the impact of land use changes over natural disasters facilitate spatial planners in making disaster-responsive land use planning decisions (Mahanama, Wimaladasa, \& Abenayake, 2014). In the given context, this study attempts to contribute to the domain of work on disaster-responsive land use planning by overcoming the key limitations of existing studies. Most of the existing studies have verified the relationship between land use and landslide incidents based on the modelled vulnerability zones and broadly classified land-use zones. Few studies which were based on empirical data too limited to spot data of hazards that do not consider the variations of the magnitude of the landslides.

The primary objective of this study is to investigate the extent in which land use changes influence on the occurrence and magnitude of landslide damages with reference to a Sri Lankan case study. Studying the influence of land use change on the frequency and magnitude of natural dsaster is vital in mainstremeing disaster risk manamgnet into urban planning (Abenayake, Mikami, Matsuda, \& Jayasinghe, 2018).

\section{Methods and materials}

\subsection{Data Acquisition}

This study is completely based on secondary data sources which were obtained from a national level database (Table 1).

Table 1: Data Acquisition

\begin{tabular}{|l|l|}
\hline Item & Source \\
\hline Landslide & $\begin{array}{l}\text { GPS- point data and Drone Survey } \\
\text { images from NBRO, Sri Lanka, 2017 } \\
\text { Damages due to the landslide, from } \\
\text { NBRO, Sri Lanka, 2017 and Disaster } \\
\text { Mangment Center, 2017 }\end{array}$ \\
\hline Land use & $\begin{array}{l}\text { Land use maps, 1:50,000 scale, from } \\
\text { Survey Department, Sri Lanka, 1986 }\end{array}$ \\
\hline Slope & $\begin{array}{l}\text { Land use maps, 1:10,000 scale, from } \\
\text { Survey Department, Sri Lanka, 2010 }\end{array}$ \\
\hline Soil & $\begin{array}{l}\text { Natiour map, 1:50,000 scale, from } \\
\text { Land Use Division, Sri Lanka, 1988 }\end{array}$ \\
\hline Rainfall & $\begin{array}{l}\text { Monthly Rainfall (1987-2017), from } \\
\text { Metelogical Department, Sri Lanka, } \\
\text { 2017 }\end{array}$ \\
\hline
\end{tabular}

Source: Prepared by author

\subsection{Selecting the study area}

Sri Lanka, as a developing country with a tropical climate, is high vulnerable for the impacts of climate change including extreme weather conditions which have been recording during unpredicted or unexpected periods of the year (Mahanama P. , Abenayake, Jayasinghe, \& Bandara, 2014); (Abenayake, M, Marasinghe, \& Takashi, 2016). National Building Research Organization (NBRO) has declared 1/3 land of Sri Lanka as landslide vulnerable areas. Data by Sri Lankan Disaster Knowledge Network of Ministry of Disaster Management reveals a growth of landslide occurrence from 2003 to 2017. Incidences of landslides in Sri Lankan context are mostly rain-induced. Recent precipitation variation studies in Sri Lanka have revealed a significant increase of rainfall in terms of intensity and frequency (Bandara, Jayasinghe, Abenayake, \& Mahanama, 2013); (Abenayake, Jayasinghe, \& Mahanama, 2013). Further, "Changes in land uses have caused "human-induced" landslides which are estimated at $80 \%$ of total landslide incidents" (Sugathapala \& Presanna, 2009) . 
Landslide-prone districts in Sri Lanka are Kalutara, Galle, Hambantota, Nuwara Eliya, Matale, Kandy, Kegalle, Ratnapura, Matara, and Badulla. Sabaragamuwa province, that consits of Kegalle and Rathnapura districts has recorded the highest vulnerability to landslides. Sabaragamuwa Province is one of the nine provinces of country which is 4968 sq. $\mathrm{km}$ in extent and holding 2 million population.

29 locations within the province, which were proned to landslides in May, 2017 were selected for the study (Fig. 1).

\subsection{Selecting an Open-Source GIS-based applications}

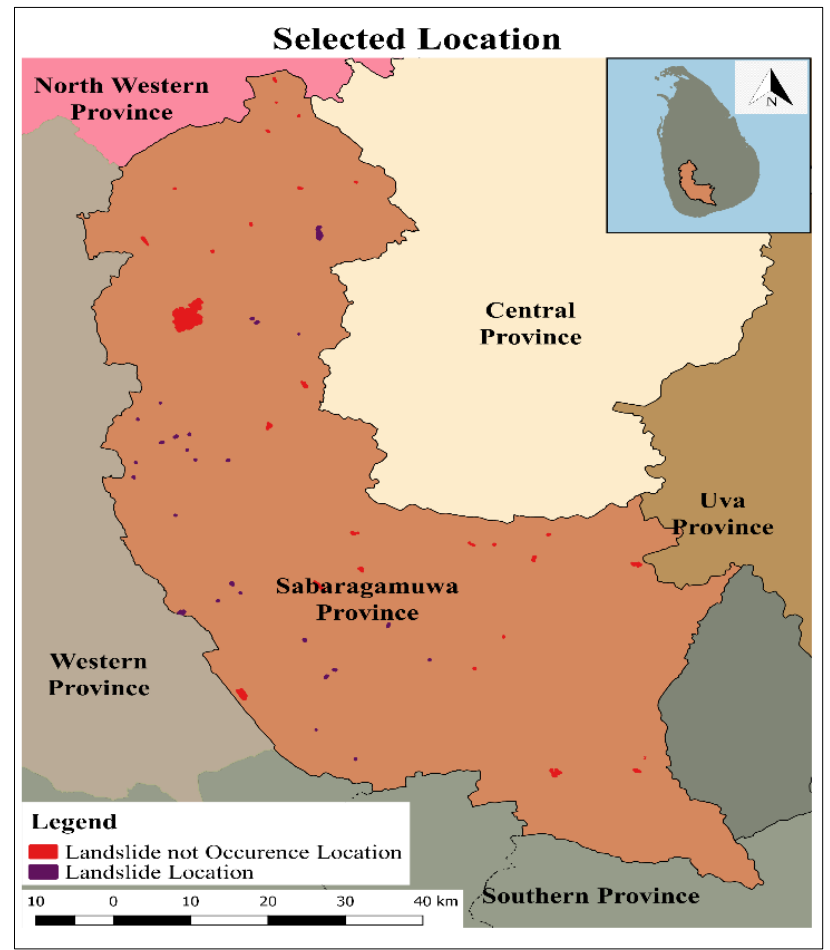

Figure 1: Study area with 29 landslide prone locations

Geographic Information System (GIS) is a widely utilized computer-based tool in disaster-responsive decisionmaking, particlulaly in anlysing temporal variations generalized by mathematical rules and represented by visual symbols (Mahanama, Jayasinghe, Jayasinghe, Bandara, \& Abenayake, 2014); (Jayasinghe, Mahanama, Senanayake, Bandara, \& Seifert, 2013). Though GIS offers a promising technical solutions to humanitarian complexties, planning and policy decision-making in developing countries often lacks funds to invest on expensive GIS applications (Mahanama, Abenayake, \& Jayasinghe, Challenge of Local Responses to Climate Change; Perceptions of Urban Planning Practitioners in Sri Lanka, 2014). (Mahanama, Jayasinghe, Jayasinghe, Bandara, \& Abenayake, 2014); (Jayasinghe, Mahanama, Senanayake, Bandara, \& Seifert, 2013). Hence, this study utilized open-source softeware in GIS environment. When considering the role of the open source GIS in landslide studies, Quantum Geographic Information System (QGIS) software allows to perform quick and convenient analysis of land cover changes. (MOLUSCE - quick and convenient analysis of land cover changes, 2013). Hence, the study utilized MOLUSCE plugin tool which is in QGIS to identify the temporal changes of land use.

\subsection{Mapping Causative factors of landslide occurrence}

Causative factors of the occurrence of landslide hazards were identified through a comprehensive literature review.

Figure 2: Slope Type of Study Area

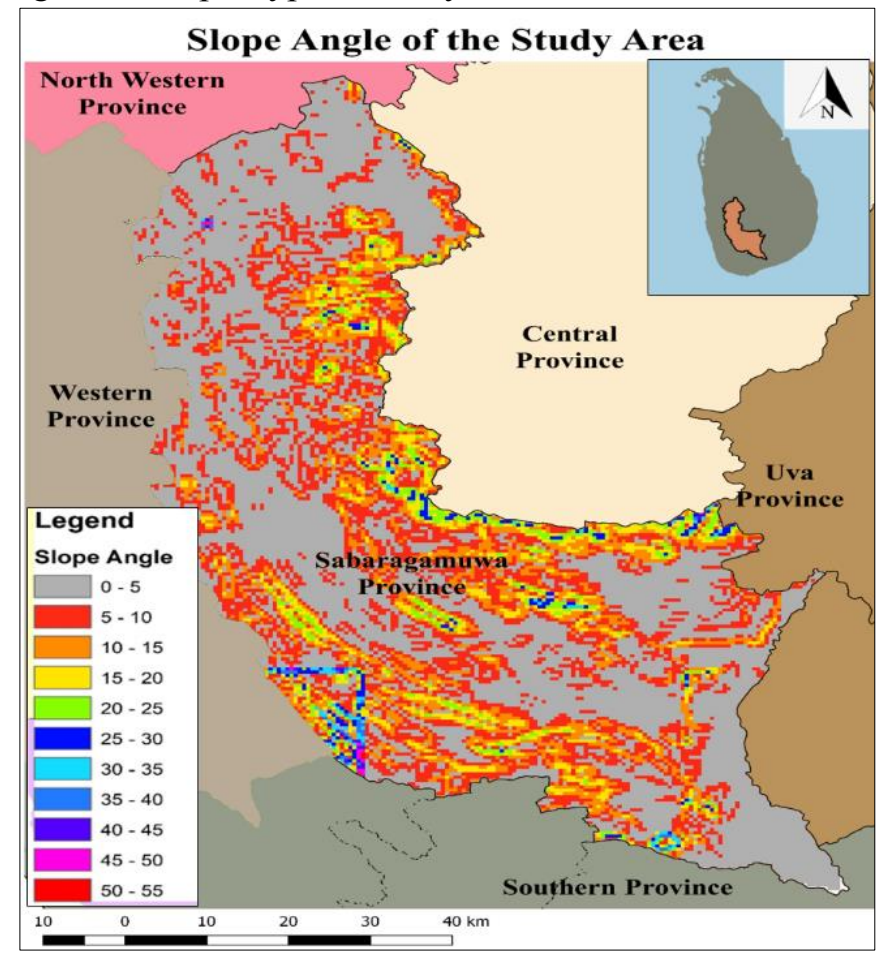

According to NBRO, causative factors of landslide hazards are bedrock geology, hydrology \& drainage, soil, slope angle range, land use and landforms (Munasinghe \& Wijegunarathne, 2015). Many authors have mentioned land use, slope, and soil as key factors (Bhandari, Perera, \& Weerasinghe, 1995); (Munasinghe S. , 2012); (Iqbal, 2014). Some authors have emphasized slope and land use as the most prominent factors among the others (Rossi, Mondini, Busca, \& Reichenbach, 2014); (Moréd, Ninyerolac, Regosa,b, \& Pons, 2015). Hence, this study has considered land use, slope, soil and precipitation as the causative factors subjected to the relative importance and data avilabilit 
As the initial step, thematic maps were prepared for the slope (Fig. 2) soil (Fig. 3), and land use in order to represent the baseline status. For that, the study utilized GPS point data and drone images.

\subsection{Detecting the temporal Changes of Landuse}

Then the study analyzed the temporal changes of land use at landslide hazard prone locations as well as within a range of spatial buffer zone areas from each landslide hazard locations. MOLUSCE (Modules for Land Use Change Evaluation) plugin in QGIS was utilized in identifing the land use changes from 1986 to 2017. There were seven different types of land use changes as depicted in Table 2 (Fig. 4)

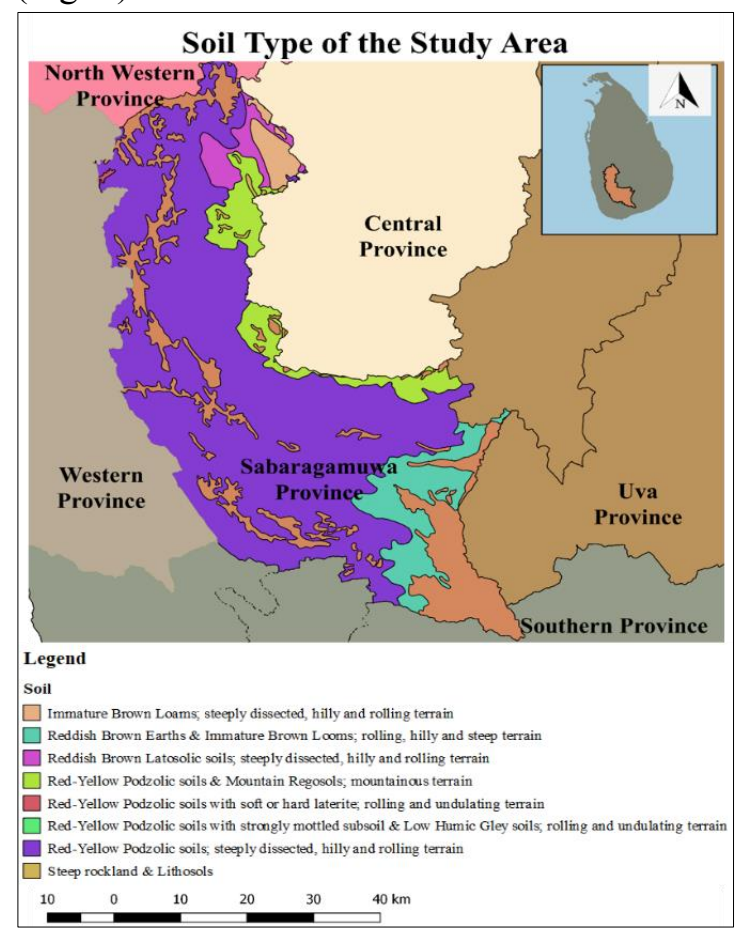

Figure 3: Soil Type of Study Area

Table 2: Land Use Changes

\begin{tabular}{|l|l|}
\hline Category & $\begin{array}{l}\text { Land Use changes 1986 } \\
-2010 \text { (sq.m) (With in } \\
\text { location) }\end{array}$ \\
\hline Garden to Tea & 81.25 \\
\hline Rubber to Other & 38.7 \\
\hline Chena to Tea & 27 \\
\hline Tea to Rubber & 7.45 \\
\hline Garden to Rubber & 154.494 \\
\hline Chena to Coconut & 0.2 \\
\hline $\begin{array}{l}\text { Rubber to } \\
\text { Coconut }\end{array}$ & 12.25 \\
\hline
\end{tabular}

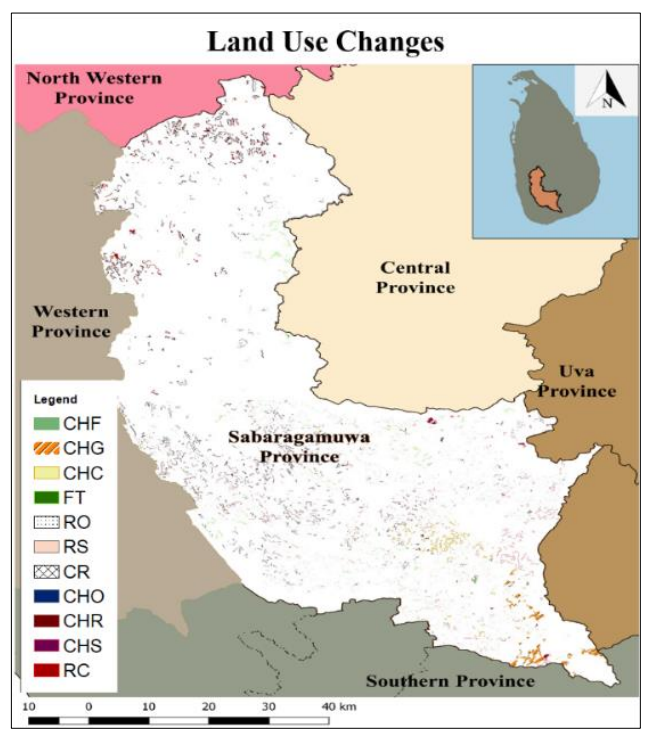

Figure 4: Land Use Change Location (Refer Table 3 for land use codes)

Table 3: Land Use Codes

\begin{tabular}{|c|c|c|c|c|c|}
\hline No & Code & Description & No & Code & Description \\
\hline 1. & ST & Scrub to Tea & 21 & SF & Scrub to Forest \\
\hline 2. & RT & Rubber to Tea & 22 & $\mathrm{CHF}$ & $\begin{array}{l}\text { Chena to } \\
\text { Forest }\end{array}$ \\
\hline 3. & GT & Garden to Tea & 23 & $\mathrm{RCH}$ & $\begin{array}{l}\text { Rubber to } \\
\text { Chena }\end{array}$ \\
\hline 4. & GR & $\begin{array}{l}\text { Garden } \\
\text { Rubber }\end{array}$ & 24 & $\mathrm{CHO}$ & Chena to Other \\
\hline 5. & FS & $\begin{array}{l}\text { Forest to } \\
\text { Scrub }\end{array}$ & 25 & OG & $\begin{array}{ll}\text { Other } & \text { to } \\
\text { Garden }\end{array}$ \\
\hline 6. & PS & $\begin{array}{ll}\text { Paddy } & \text { to } \\
\text { Garden } & \\
\end{array}$ & 26 & FR & $\begin{array}{ll}\text { Forest } & \text { to } \\
\text { Rubber } & \\
\end{array}$ \\
\hline 7. & FT & Forest to Tea & 27 & SF & Scrub to Forest \\
\hline 8. & SR & $\begin{array}{l}\text { Scrub to } \\
\text { Rubber }\end{array}$ & 28 & $\mathrm{FO}$ & Forest to Other \\
\hline 9. & RG & $\begin{array}{ll}\text { Rubber } & \text { to } \\
\text { Garden } & \\
\end{array}$ & 29 & FG & $\begin{array}{ll}\text { Forest } & \text { to } \\
\text { Garden } & \end{array}$ \\
\hline 10. & TS & Tea to Scrub & 30 & PS & Paddy to Scrub \\
\hline 11. & SG & $\begin{array}{ll}\text { Scrub } & \text { to } \\
\text { Garden } & \\
\end{array}$ & 31 & $\mathrm{CHC}$ & $\begin{array}{l}\text { Chena to } \\
\text { Coconut }\end{array}$ \\
\hline 12. & $\mathrm{PO}$ & $\begin{array}{l}\text { Paddy } \\
\text { Other }\end{array}$ & 32 & OR & $\begin{array}{ll}\text { Other } & \text { to } \\
\text { Rubber } & \\
\end{array}$ \\
\hline 13. & $\mathrm{RC}$ & $\begin{array}{l}\text { Rubber to } \\
\text { Coconut }\end{array}$ & 33 & $\mathrm{CR}$ & $\begin{array}{l}\text { Coconut to } \\
\text { Rubber }\end{array}$ \\
\hline 14. & RO & $\begin{array}{l}\text { Rubber to } \\
\text { Other }\end{array}$ & 34 & $\mathrm{OC}$ & $\begin{array}{l}\text { Other to } \\
\text { Coconut }\end{array}$ \\
\hline 15. & RS & $\begin{array}{l}\begin{array}{l}\text { Rubber } \\
\text { Scrub }\end{array} \\
\end{array}$ & 35 & $\mathrm{FCH}$ & $\begin{array}{ll}\begin{array}{l}\text { Forest } \\
\text { Chena }\end{array} & \text { to } \\
\end{array}$ \\
\hline 16. & CR & Chena Rubber & 36 & $\mathrm{SCH}$ & Scrub to Chena \\
\hline 17. & $\mathrm{TR}$ & Tea to Rubber & 37 & CHT & Chena to Tea \\
\hline 18. & TG & Tea to Garden & 38 & $\mathrm{CHG}$ & $\begin{array}{ll}\text { Chena } & \text { to } \\
\text { Garden } & \end{array}$ \\
\hline 19. & CS & $\begin{array}{l}\text { Chena to } \\
\text { Scrub }\end{array}$ & 39 & $\mathrm{TCH}$ & Tea to Chena \\
\hline 20. & $\mathrm{CHC}$ & $\begin{array}{l}\text { Chena to } \\
\text { Coconut }\end{array}$ & & & \\
\hline
\end{tabular}

This study employed specific buffers to the landslide occurrence locations vary from $500 \mathrm{~m}$ to $5 \mathrm{~km}$. Figure 5 and 6 represent the buffer zone which used in this study. 


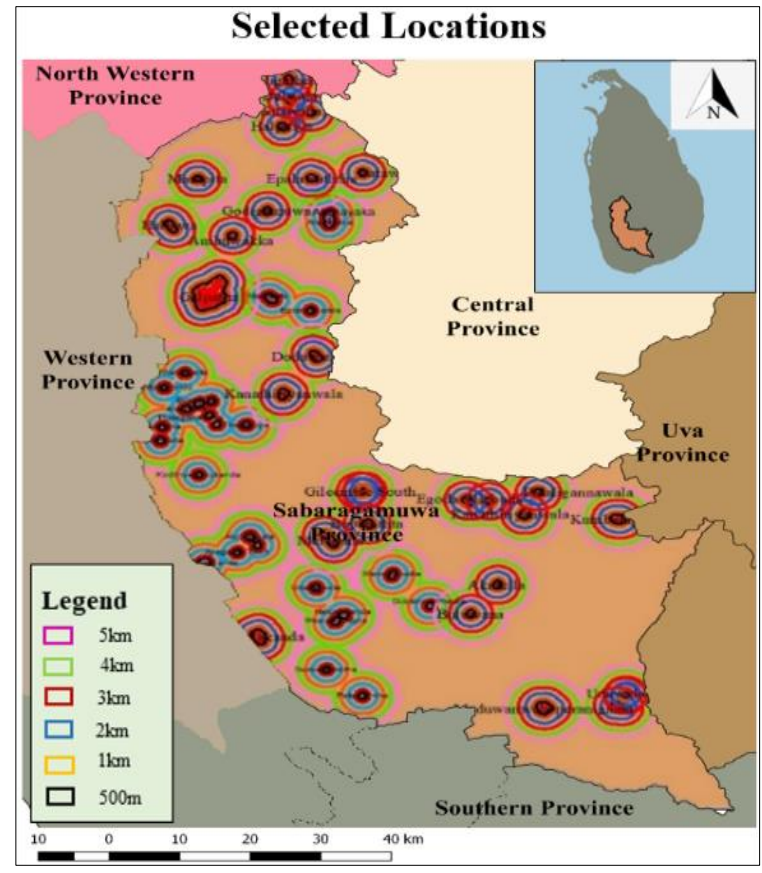

Figure 5: Selected location with 29 land slide locations

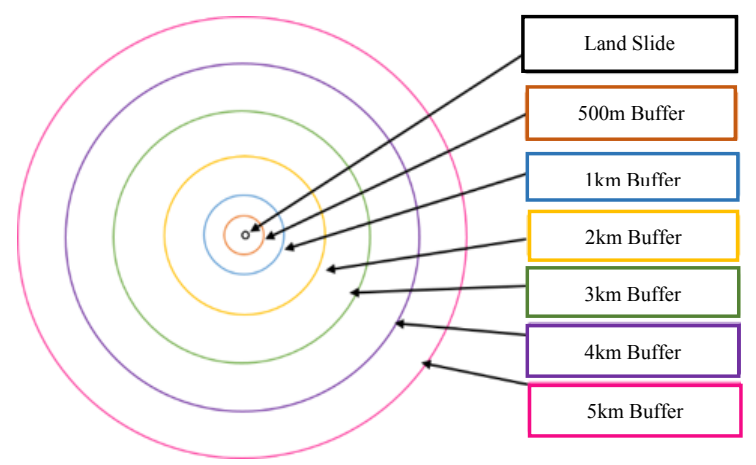

Figure 6: Buffer Zones

\subsection{Mapping the occurrence and magnitude of Indslides}

The study referred five indicators related to the magnitude of landslide damage; the percentage of death, injured, partially damaged buildings, fully damaged buildings and affected population as follows. The referred indicators were classified into five classes as depicted in table 4.

Equation 1 was employed to normalize the data into categorical variables of 5 classes.

Equation 1: Formula of equal interval classification method

$\frac{\text { Range of data }}{\text { Number of class }}=\frac{\text { (Highest value }- \text { lowest value })}{\text { Number of class }}$

Table 4: Weighted Table

\begin{tabular}{|c|c|c|c|c|c|}
\hline $\begin{array}{l}\frac{\overrightarrow{0}}{.00} \\
\frac{.00}{0} \\
3\end{array}$ & 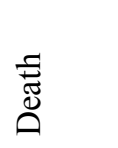 & 惫 & 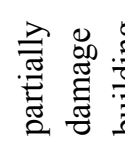 & 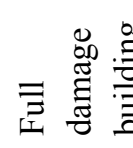 & 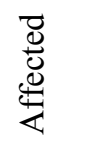 \\
\hline 1 & $<29$ & $<19$ & $<29$ & $<30$ & $<1015$ \\
\hline 2 & $30-59$ & $20-39$ & $30-59$ & $31-61$ & $\begin{array}{l}1016- \\
2031\end{array}$ \\
\hline 3 & $60-89$ & $40-59$ & $60-89$ & $62-92$ & $\begin{array}{l}2032- \\
3047\end{array}$ \\
\hline 4 & $90-119$ & $60-79$ & $90-119$ & $93-123$ & $\begin{array}{l}3048- \\
4063\end{array}$ \\
\hline 5 & $120<$ & $80<$ & $120<$ & $124<$ & $4064<$ \\
\hline
\end{tabular}

Equation 2 was employed in computing the percentage of deaths and Equa.3 was employed in computing the aggregated value of the magnitude of the landslide damage.

Equation 2: Formula of percentage of death

\begin{tabular}{l}
$\begin{array}{l}\text { Percentage of } \\
\text { death }\end{array}$ \\
\hline
\end{tabular}

Equation 3: Formula of Final Damage

Final damage weight $=$ death $*$ injured $*$ partially damage building * full damage building* affected population

Slope, rainfall and soil values were also classified into 5 categories of equal class intervals (Table 5,6 and 7).

Table 5: Weighted table of Slope angle

\begin{tabular}{|l|l|l|}
\hline Slope range & Weight & Description \\
\hline $0-5 / 5-10$ & 1 & Low \\
\hline $20-45$ & 3 & Medium \\
\hline $10-20 / 45-50$ & 5 & High \\
\hline
\end{tabular}

Table 6: Weighted table of Rainfall

\begin{tabular}{|l|l|l|}
\hline Rainfall weight & Weight & Description \\
\hline$<335$ & 1 & Low \\
\hline $335-670$ & 3 & Medium \\
\hline$>670$ & 5 & High \\
\hline
\end{tabular}




\subsection{Analyzing the association between the magnitude of landslide damage and land use changes}

Next, the study tested the association between each landslide location (29 locations) and land use change locations (30 locations). This step was supported by MSExcel spreadsheet and QGIS to calculating the land use change (39 land use change types) by area and percentage in each buffer (420 buffers).

This study conducted relationship analysis at three levels as follows. The first level is to detect whether the identified causative factors have influenced on the occurrence and non-occurrence of landslides statistically by utilizing ANOVA analysis. The second level is the identification of the degree and association of the selected causative factors with the magnitude of landslides damage by utilizing correlation analysis. The third level is validation of the causative factors using Multi-layer Perception Analysis. The graphical summary of the method of study is depicted in Fig.7.

Table 7: Weighted table of Soil

\begin{tabular}{|l|l|l|}
\hline Soil type & Soil weight & Description \\
\hline All other & 1 & Low \\
\hline $\begin{array}{l}\text { Red-Yellow } \\
\text { Podzolic soils and } \\
\text { Mountain } \\
\text { Regosols; } \\
\text { mountainous terrain }\end{array}$ & 3 & Moderate \\
\hline $\begin{array}{l}\text { Red-Yellow soils; } \\
\text { Podzolic } \\
\text { steeply dissected, } \\
\text { hilly and rolling } \\
\text { terrain }\end{array}$ & 5 & High \\
\hline
\end{tabular}

\section{Results and Discussion}

First, the study performed one-way ANOVA test in SPPS to identify the statistically significant differences between landslide occurrence and not occurrence groups with the identified causative factors (soil type, slope class, rainfall and land use changes). Table 8 indicates the summary results of the one-way ANOVA test. Statistical analysis of one-way ANOVA demonstrated a significant variance of slope $(\mathrm{P}<0.001)$ and soil type $(\mathrm{P}<0.001)$ between the groups of landslide-prone and landslide non-prone groups. Further, this variance was significant among land use change categories such as forest to rubber (FR) $(\mathrm{P}<0.001)$, rubber to coconut $(\mathrm{RC})(\mathrm{P}<0.001)$, rubber to home gardens (RG) $(\mathrm{P}<0.001)$ and rubber to other land use $(\mathrm{RO})$ $(\mathrm{P}<0.001)$.

Secondly, the study analyzed the association between the causative factors and the magnitude of the occurrence of landslides by utilizing Spearmen's correlation coefficient analysis in SPSS. Figure 8 depicts the summary results of correlation analysis. The highly significant strong, positive correlations were revealed in the magnitude of landslides and land use changes including 'rubber to other' $(\mathrm{r}=0.7$ $\mathrm{p}<.01)$, 'forest to other' $(\mathrm{r}=0.7 \mathrm{p}<.01)$, 'tea to rubber' ( $\mathrm{r}=$ $0.6 \mathrm{p}<.01)$ and 'rubber to home garden' $(\mathrm{r}=0.55 \mathrm{p}<.01)$. Accordingly, it was clear that higher the extent of land use changes from high-canopy vegetation to low-canopy vegetation and vegetation to built-up areas, higher the magnitude of landslide damage.

Next, the study employed Multi-layer Perceptron Analysis (MPA) to validate the multiple influence of causative factors on occurrence of the landslide by expert's opinion. There were three stakeholder groups and the occurrence of the landslide was the dependent variable. In this analysis, dataset was formed into two samples as training and testing (65.3\% - training data set and $34.7 \%$ - testing data set). Figure 10 depicts the model and Table 9 presents the network information of the model. The study categorized the occurrence of landslide into 6 groups such as 'no landslide occurrence' and landslide occurrences at different magnitudes from 1 to 5 . Table 10 indicates the accuracy of the model. Error of the model is 1.131 and the percent incorrect prediction is $0.0 \%$. It indicated that the model is accuracte.

Figure 8 depicts the normalized importance of the identified causative factors on occurrence of landslide, which was derived from the model. The results of the model indicated that the soil type and land use changes such as 'rubber to any' within $1 \mathrm{~km}$ and $2 \mathrm{~km}$ buffer area; 'forest to any' within $3 \mathrm{~km}$ buffer area; 'tea to any' within $1 \mathrm{~km}$ buffer area have significant influence on occurrence of landslides ( $70 \%$ normalize importance). This indicates the changes of vegetative land uses such as forest, tea and rubber into any other type may trigger the landslide occurrences and damages. 
Figure 7: Steps of the Study

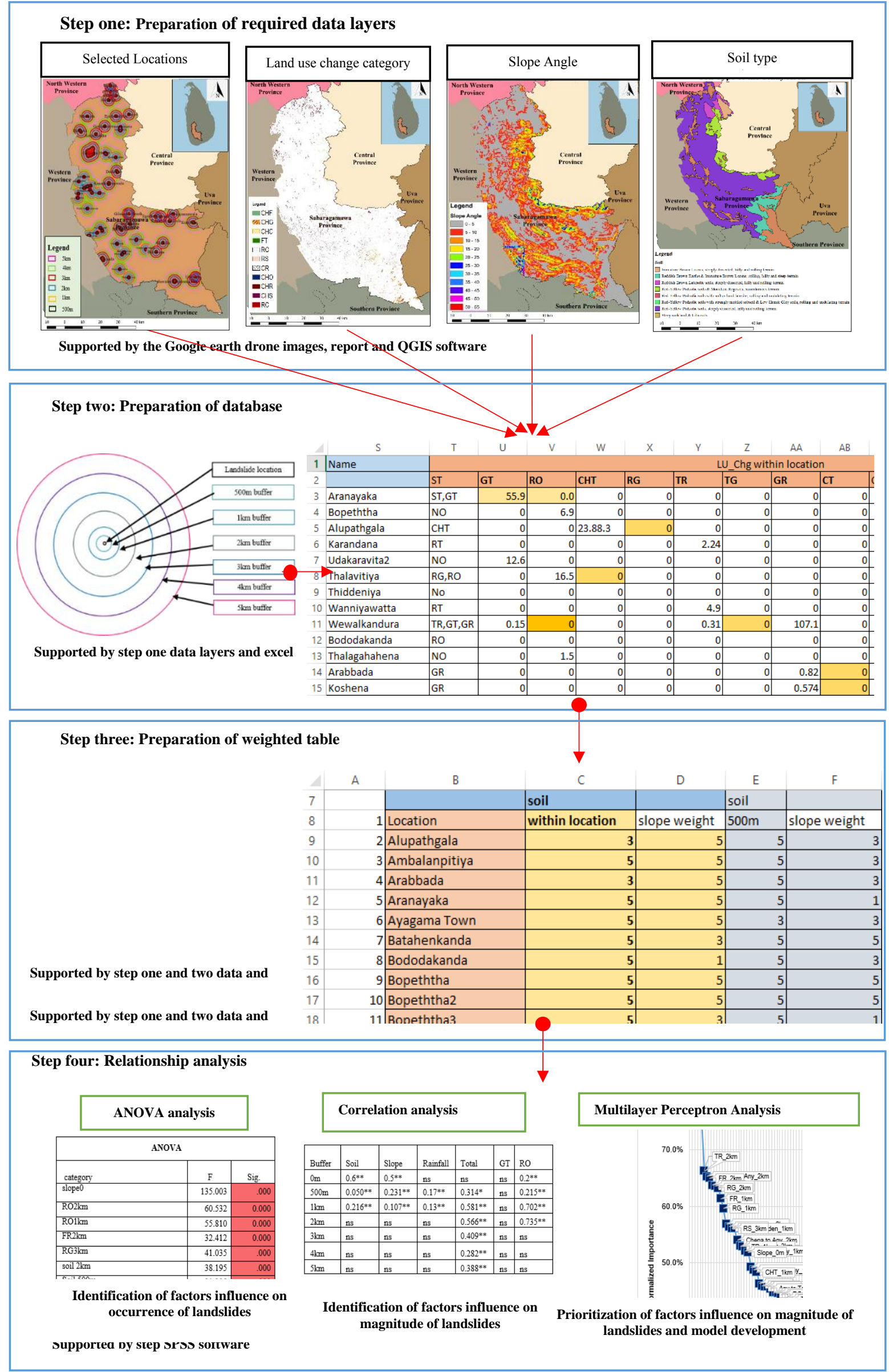


Table 9: Network Information

\begin{tabular}{|l|l|l|}
\hline \multicolumn{2}{|l|}{ Network Information } \\
\hline \multicolumn{2}{|l|}{ Number of Factors } & 143 \\
\hline $\begin{array}{l}\text { Rescaling Method for } \\
\text { Covariates }\end{array}$ & Standardized \\
\hline $\begin{array}{l}\text { Hidden } \\
\text { Layers }\end{array}$ & $\begin{array}{l}\text { Number of Hidden } \\
\text { Layers }\end{array}$ & 1 \\
\cline { 2 - 3 } & $\begin{array}{l}\text { Number of Factors } \\
\text { in Hidden Layer 1 }\end{array}$ & 10 \\
\cline { 2 - 3 } & Activation Function & $\begin{array}{l}\text { Hyperbolic } \\
\text { tangent }\end{array}$ \\
\hline $\begin{array}{l}\text { Output } \\
\text { Layer }\end{array}$ & $\begin{array}{l}\text { No. of Dependent } \\
\text { Variables }\end{array}$ & 1 \\
\cline { 2 - 3 } & \begin{tabular}{l} 
Dependent Variable \\
\cline { 2 - 3 }
\end{tabular} & Occurrence of \\
& Number of Units & 6 \\
\cline { 2 - 3 } & Activation Function & Softmax \\
\cline { 2 - 3 } & Error Function & Cross-entropy \\
\hline
\end{tabular}

Table 10: Accuracy of the Model

\begin{tabular}{|c|c|c|}
\hline \multicolumn{3}{|c|}{ Model Summary } \\
\hline \multirow[t]{4}{*}{ Training } & $\begin{array}{l}\text { Cross Entropy } \\
\text { Error }\end{array}$ & $1.131 \%$ \\
\hline & $\begin{array}{l}\text { Percent } \\
\text { Incorrect } \\
\text { Predictions }\end{array}$ & $0.0 \%$ \\
\hline & $\begin{array}{l}\text { Stopping Rule } \\
\text { Used }\end{array}$ & $\begin{array}{l}1 \text { consecutive } \\
\text { step(s) with no } \\
\text { decrease in } \\
\text { error }^{\mathrm{a}}\end{array}$ \\
\hline & Training Time & $5 \mathrm{~S}$ \\
\hline \multirow[t]{2}{*}{ Testing } & $\begin{array}{l}\text { Cross Entropy } \\
\text { Error }\end{array}$ & $2.072 \%$ \\
\hline & & $1.7 \%$ \\
\hline \multicolumn{3}{|c|}{ Dependent Variable : Damage Weight } \\
\hline \multicolumn{3}{|c|}{$\begin{array}{l}\text { a. Error Computations are Based on the } \\
\text { Testing Sample }\end{array}$} \\
\hline
\end{tabular}

\section{Conclusion}

The primary objective of this study was to investigate the extent in which land use changes are influenced on the occurrence and the magnitude of landslide damages. Sabaragamuwa province in Sri Lanka was selected as the study area. The research was executed in four steps as: secondary data collection on landslide occurrences and preparation of GIS database; preparation of database on land use changes with buffers (as $0 \mathrm{~m}, 500 \mathrm{~m}, 1 \mathrm{~km}, 2 \mathrm{~km}$, $3 \mathrm{~km}$ and $5 \mathrm{~km}$ ); identification of magnitude of the landslide; and analyzing the degree of association between land use change and landslide damage. The study utilized open-source software applications including QGIS and MOLUSCE plugin. Relationship analysis were conducted in three levels by performing ANOVA analysis to identify the of factors influence on the occurrence of landslides; correlation analysis to test the association between causative factors and different types of land use changes; and multilayer perceptron Analysis to validate factors influence on the magnitude of landslides and model development.

The study identified that land use changes such as forest to rubber, rubber-to-garden, rubber-to-any, tea-to-rubber, teato-any, forest-to-any have recorded a greater influence on high occurrence of high magnitude of landslides.

These findings represent an important step towards the better understanding of the influence on land use changes by the magnitude of landslide damage.

The findings can be useful in making land use planning decisions in minimizing landslide damages, particularly in the fields of land use planning and disaster management.

\section{Acknowledgements}

The study team acknowledge NBRO, Disaster Management center \& Department of meteorology, Sri Lanka for providing free access to data. 


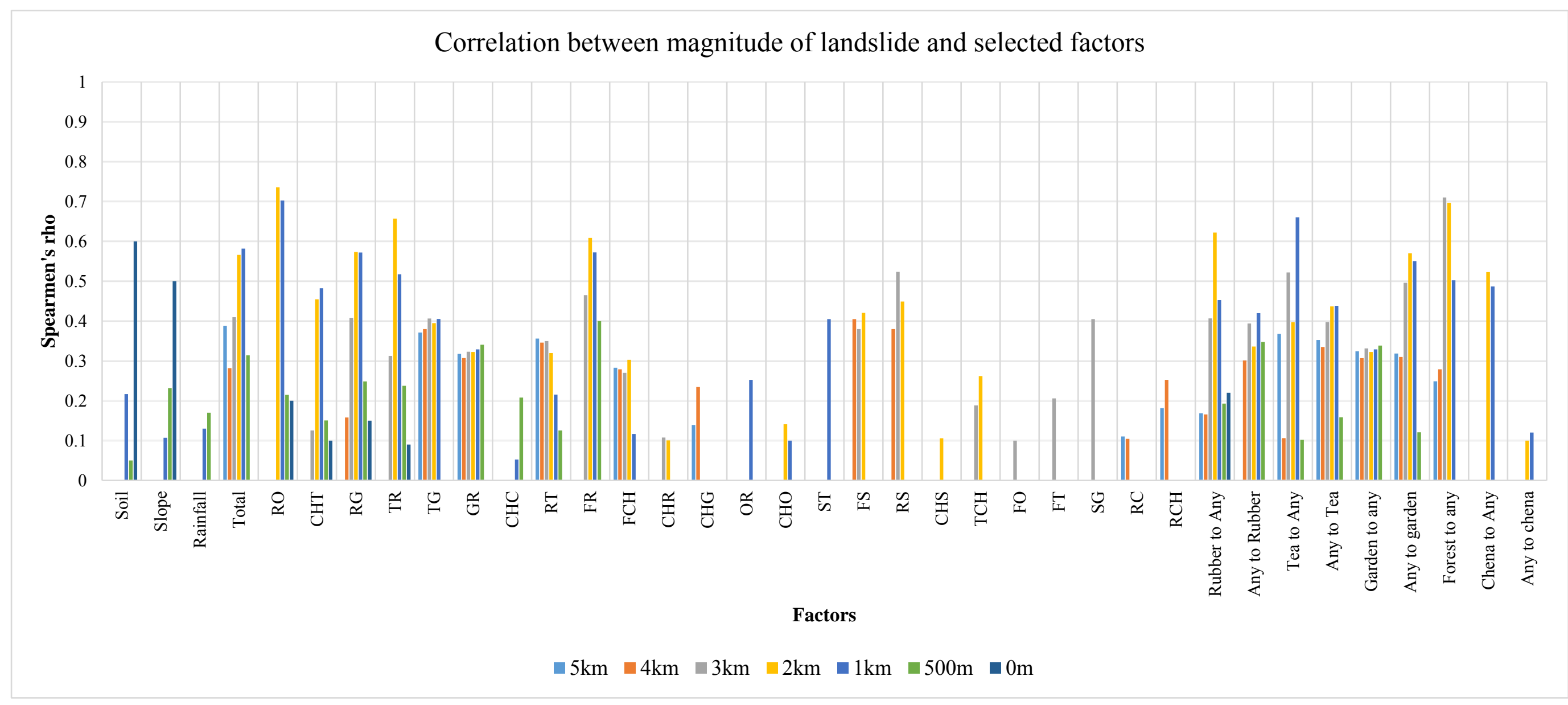

Figure 8: Summary results of correlation analysis 


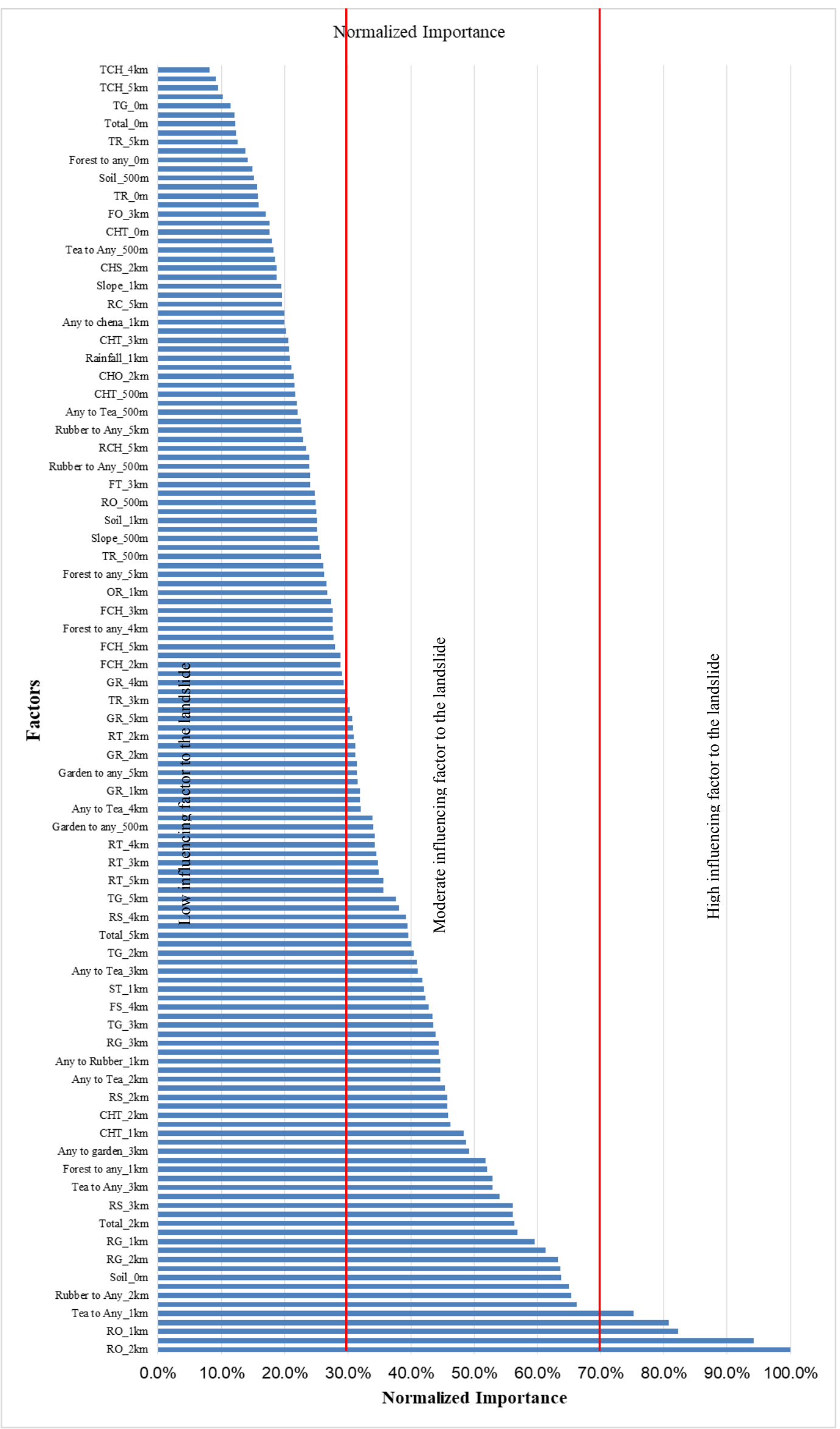

Figure 9: Normalized importance of the identified causative factors on occurrence of landslide 
Table 8: Summary of ANOVA Analysis

\begin{tabular}{|c|c|c|c|c|c|c|c|c|c|c|c|c|c|c|}
\hline Buffer & Slope & Soil & Rainfall & FR & $\mathrm{RC}$ & RT & TG & RG & TR & $\mathrm{CHR}$ & $\mathrm{FCH}$ & RO & GR & CHT \\
\hline $0 \mathrm{~m}$ & 0.000 & 0.000 & 0.003 & & & & & 0.097 & 0.073 & & & 0.016 & & \\
\hline $500 \mathrm{~m}$ & 0.004 & 0.000 & 0.003 & 0.041 & & 0.037 & & 0.011 & 0.042 & & & 0.001 & & \\
\hline $1 \mathrm{~km}$ & 0.000 & 0.015 & 0.003 & 0.000 & 0.000 & 0.003 & 0.005 & 0.008 & & & & & & \\
\hline $2 \mathrm{~km}$ & 0.000 & 0.000 & & 0.000 & & 0.001 & 0.003 & 0.000 & 0.002 & & & 0.000 & 0.000 & 0.006 \\
\hline $3 \mathrm{~km}$ & 0.000 & & 0.003 & & & 0.002 & 0.038 & 0.000 & 0.009 & 0.048 & 0.050 & & & \\
\hline $4 \mathrm{~km}$ & & & 0.003 & & & & & 0.010 & & & & & & \\
\hline $5 \mathrm{~km}$ & & & & & & 0.043 & & & & & 0.013 & & & \\
\hline 0.000 & Higest & significa & ant $(\mathrm{P}<0.0$ & 000) & & & & & & & & & & \\
\hline 0.004 & Second & lly signif & ficant $(\mathrm{P}<0$ & $0.01)$ & & & & & & & & & & \\
\hline 0.015 & Thirdly & signific & ant $(\mathrm{P}<0$. & & & & & & & & & & & \\
\hline
\end{tabular}

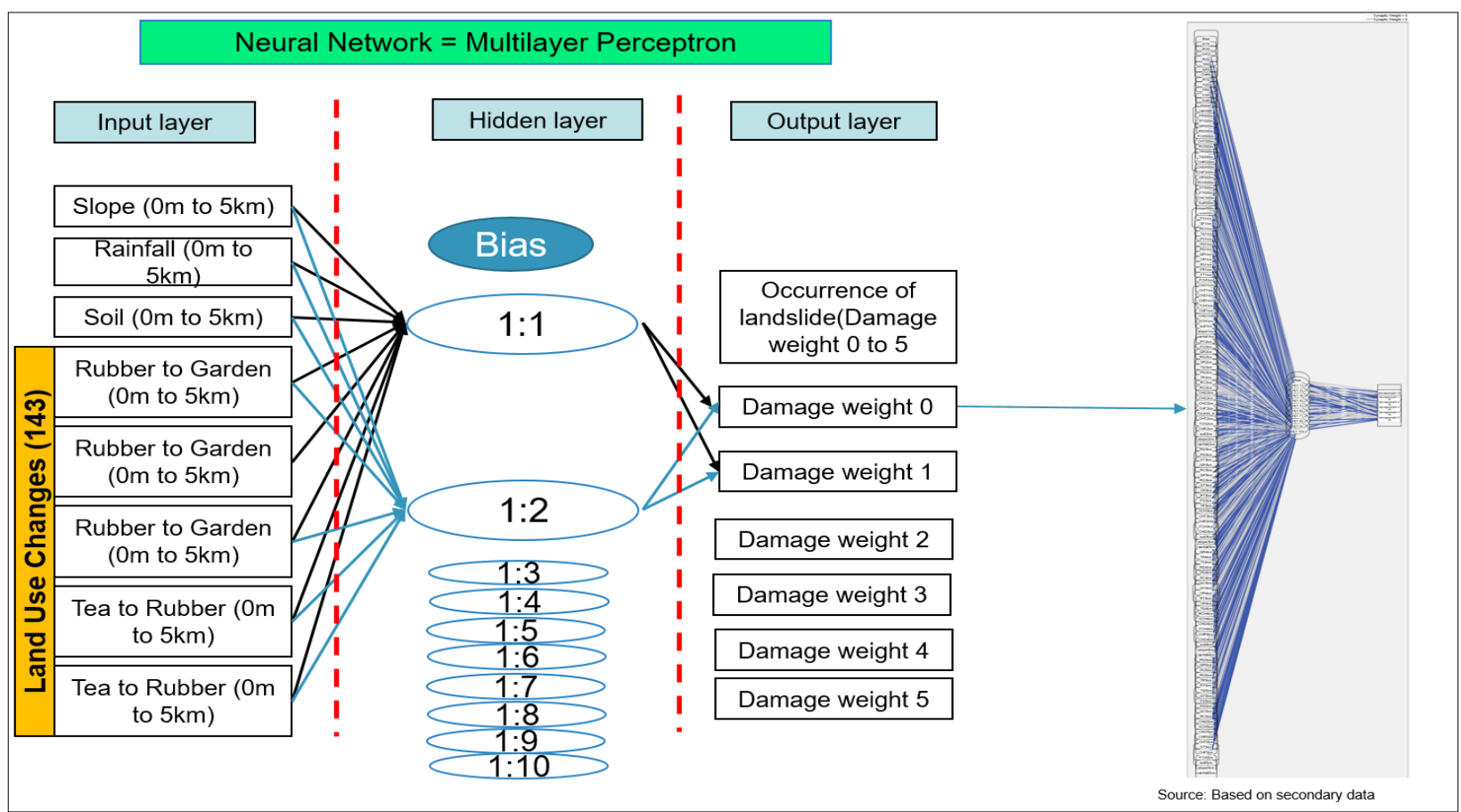

Figure 10: Diagram of multilayer perceptron analysis 


\section{Reference}

Abenayake, C., M, Y., Marasinghe, A., \& Takashi, Y. (2016). Applicability of Extra-Local Methods for AssessingCommunity Resilience to Disasters: A Case of Sri Lanka. Journal of Environmental Assessment Policy and Management, 18(2), 1-33.

Abenayake, C., Mikami, Y., Matsuda, Y., \& Jayasinghe, A. (2018, September). Ecosystem servicesbased composite indicator for assessing community resilience to floods. Environmental Development , $27,34-46$.

Agliardi, F. (2017, Auguest 15). Landslide definition. Retrieved from Geology.cz: http://www.geology.cz

Alewell, C., \& Meusburger, C. (2008). Impacts of anthropogenic and environmental factors on the. Natural Hazards \& Earth System Science, 509-520.

Almeida, C. M., \& Gleriani, J. M. (2005). Cellular Automata and Neural Networks as a Modelling Framework for the Simulation of Urban Land use Change. Anais XII Simposio Brasileir de Senariamento, Goiania, (pp. 3697-3705). Brasil.

Anthony , Y. G.-O., \& Li, X. (2002). Urban Simulation Using Neural Networks and Cellular Automata for Land Use Planning. Symposium on Geospatial Theory, (pp. 1-14). Ottawa.

Applying geoscience to Australia's most important challenges. (2017, Auguset 5). Retrieved from Australian Government: http://www.ga.gov.au

Bakker, M., Govers, G., Kosmas, C., Vanacker, V., Rounsevell, M., \& Oost, K. V. (2005, February). Soil erosion as a driver of land-use change. Agriculture, Ecosystems \& Environment, 105(3), 467-481.

Bandara, P., Jayasinghe, A., Abenayake, C., \& Mahanama, P. (2013). Study on the trends of rainfall and temperature patterns to identify the influence of climate variation in coastal cities in Sri Lanka. Moratuwa: FARU Conference-2013, Faculty of Architecture Research Unit, University of Moratuwa (December 2013).

Beek, L., \& Asch, W. (2004). Regional Assessment of the Effects of Land-Use Change on Landslide Hazard By Means of Physically Based Modelling. Unknown.

Bhandari, D., Perera, M., \& Weerasinghe, K. M. (1995). Application Of Geographic Information System (Gis) In Landslide Hazard Mapping At The National Building Research Organization . NATIONAL BUILDING RESEARCH ORGANIZATION.

Clarke, K., \& Hoppen, S. (1997). A self-modifying cellular automaton model of historical urbanization in the San Francisco Bay area. Environment and Planning B: Planning and Design, 24, 247 - 261.

Cruickshanka, R. (1995). Manual on field mapping for landslide hazard zonation. Colombo: NBRO.

Delavar, M., Mohammadi, S., \& Pahlavani, P. (2014). Urban Growth Modeling using an artificial neural network A case study of sanadajsity. 1st ISPRS International conference on Geospatial information research, $X L-2 / W 3,2014$, pp. 203-208. Iran.

Disaster Management Center. (2017, June 30). Retrieved from Disinventra: Http://Www.Desinventar.Lk

Disaster Management Centre . (2017, June 30). Disaster MAnagement centre. Retrieved from Disinventor: http://www.desinventar.lk

Earth science. (2017, July 25). Retrieved from Study.com: http://study.com/academy

Eeckhaut, V. (2009). Landslide Databases - State of Research. In Unkown, Landslide Databases as Tools for Integrated Assessment of Landslide Risk (pp. 25-40). Switzerland: Springer International Publishing.

FLambin, E., \& Serneels, S. (2001). Proximate causes of land-use change in Narok District, Kenya: a spatial statistical model. Agriculture, Ecosystems \& Environment, 65-81. 
Gail A., C., Sucharith, G., Byron, M., \& Curtis E, W. (n.d.). A Neural Network Method for Land Use Change Classification, with Application to the Nil River Delta. Boston.

Gismondi, M. (2013). MOLUSCE - An Open Source Land Use Change Analyst. FOSS4G Nottingham 2013. FOSS4G .

Giuseppina, M., Bordoni, M., \& Meisina, C. (2017). The role of land use changes in the distribution of shallow landslides. Science of The Total Environment, 924-937.

Giuseppina, M., Massimiliano, P., \& Clau, B. (2017, January 1). The role of land use changes in the distribution of shallow landslides. Science of The Total Environment, 574, 924-937.

Greenway, D. (1987). Vegetation and slope stability. Agricultural Sciences, 187-230.

Iqbal, M. a. (2014). Spatiotemporal Land Use Land Cover change analysis and erosion risk mapping of Azad Jammu and Kashmir, Pakistan. he Egyptian Journal of Remote Sensing and Space Science, 209229.

Jayasinghe, A., Mahanama, P., Senanayake, D., Bandara, L., \& Seifert, I. (2013). Participatory GIS (PGIS) as a tool for Flood Mapping in climate change adaptation : a study of Batticaloa city, Sri Lanka. Hamburg : European Climate Change Adaptation Conference (ECCA) 2013.

Jayathilake, D., \& Munasinghe, D. (2015). Quantitative Landslide Risk Assessment and Mapping. In NBRO, National building Reseach Organization symposium "Inovation For Resilient Environment. Sri Lanka.

Jayathilake, D., \& Munasinghe, D. (2015). Quantitative Landslide Risk Assessment and Mapping. Colombo: National Building Research Organisation.

Kasim, A., Wicsksono, A., \& Kurniawan, E. (2017). The Integration level of public transportation in Makassar city. 3rd Interntional conference of planning, (pp. 1-4).

Mahanama, P., Abenayake, C., \& Jayasinghe, P. (2014). Challenge of Local Responses to Climate Change; Perceptions of Urban Planning Practitioners in Sri Lanka. Asian Journal of Humanities and Social Studies, 2(4), 506-512.

Mahanama, P., Abenayake, C., Jayasinghe, A., \& Bandara, P. (2014). CLIMATE RESPONSES OF LOCAL AUTHORITIES: A CASE OF SRI LANKAN COASTAL URBAN AREAS. International Journal of Research In Social Sciences, 4(3), 59-66.

Mahanama, P., Jayasinghe, A., Jayasinghe, K., Bandara, R. B., \& Abenayake, C. (2014). Assesse the level of vulnerability in Sri Lankan coastal areas to climate exaggerated disasters: Application of Analytical Hierarchical Process (AHP) and Geographic Information System (GIS) . International Journal of Advanced Research, 2(8), 523-534.

Mahanama, P., Wimaladasa, J., \& Abenayake, C. (2014). CHALLENGES IN LOCAL RESPONSES TO CLIMATE CHANGE; A CASE OF URBAN ADAPTATIONS IN SRI LANKA. Third International Conference on Climate Change \& Social Issues 2014 (pp. 47-51). Colombo: International Center for Research and Development. Retrieved August 13, 2018

MOLUSCE - quick and convenient analysis of land cover changes. (2013, November 3). Retrieved from NEXTGIS: http://nextgis.com/blog/molusce/

Moréd, G., Ninyerolac, M., Regosa,b, A., \& Pons, X. (2015). Linking land cover dynamics with driving forces in mountain landscape of the Northwestern Iberian Peninsula. International Journal of Applied Earth Observation and Geoinformation, 1-14.

Munasinghe, D., \& Wijegunarathne, E. (2015). Vulnerability Assessment Methods for Land Subsidence Prone Areas. In NBRO, International symposium (pp. 1-7).

Munasinghe, S. (2012). GIS MODELLING FOR INCREASE THE ACCURACY ON LANDFORM MAPPING. Colombo: NBRO. 
N.Vithana, Withana, T. N., Rathnayake, R. M., Rathuwadu, C. L., Tharusha, S. S., \& Ramanyaka, R. T. (2014). "Asani Wasi"- A Landslide Early Warning System. PNCTM, 13-17.

Onuwa, O., Isong, M., Eyoh, A., Nwanekezie, O., Olayinka, D. N., Udoudo, D. O., \& Ofem, B. (2012). GIS Cellular Automata Using Artificial Neural Network for Land Use Change Simulation of Lagos,Nigeria. Geography \& Geology, 94-101.

Ranjan, E., \& Abenayake, C. (2014). A Study on Community's Perception on Disaster Resilience Concept. Procedia Economics and Finance, 18, 88-94.

Rossi, M., Mondini, A., Busca, C., \& Reichenbach, P. (2014). The Influence of Land Use Change on Landslide Susceptibility Zonation: The Briga Catchment Test Site (Messina, Italy). Environmental Management, 1372-1384.

Sugathapala, K., \& Presanna, L. (2009). Essential Human Settlement Planning Considerations for SustainableLandslideMitigation:With Special Reference to Padiyapelella Landslide Area.

Vliet, v. J., Hurkens, J., White, R., \& Delden, v. H. (2012). An activity-based cellular automaton model to simulate land-use dynamics. Environment and Planning B: Planning and Design, 198-212.

Weng, Q. (2002). Land use change analysis in the Zhujiang Delta of China using satellite remote sensing, GIS and stochastic modelling. Journal of Environmental Management, 273-284.

Jayasinghe, P., Bandara, N., Jayasinghe, A. B., Chemin, Y., \& Mahanama, P. K. S. (2015). Assess the Level of Vulnerability to Climate Induced Disasters in Sri Lankan Coastal Areas: An Application of Open Source Geographic Information System. International Journal of Geoinformatics, 11(3). 